\title{
Law and Prudence in the Law of Justiciability: The Transformation and Disappearance of the Political Question Doctrine
}

Mark V. Tushnet

Georgetown University Law Center, tushnet@law.georgetown.edu

This paper can be downloaded free of charge from:

https://scholarship.law.georgetown.edu/facpub/254

80 N.C. L. Rev. $1203-1235$ (2002)

This open-access article is brought to you by the Georgetown Law Library. Posted with permission of the author. Follow this and additional works at: https://scholarship.law.georgetown.edu/facpub

Part of the Jurisprudence Commons, and the Law and Politics Commons 


\title{
GEORGETOWN LAW Faculty Publications
}

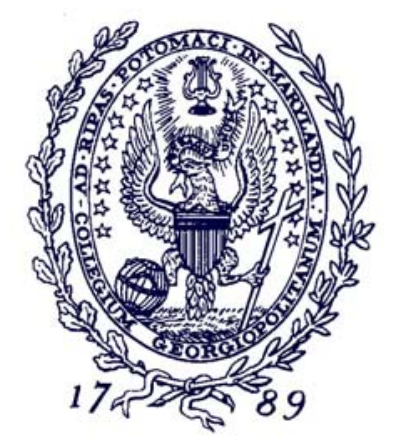

February 2010

\section{Law and Prudence in the Law of Justiciability: The Transformation and Disappearance of the Political Question Doctrine}

\author{
80 N.C. L. Rev. 1203-1235 (2002) \\ Mark V. Tushnet \\ Professor of Law \\ Georgetown University Law Center \\ tushnet@law.georgetown.edu
}

This paper can be downloaded without charge from:

Scholarly Commons: http://scholarship.law.georgetown.edu/facpub/254/

SSRN: $\underline{\text { http: //ssrn.com/abstract }=283464}$

Posted with permission of the author 


\title{
LAW AND PRUDENCE IN THE LAW OF JUSTICIABILITY: THE TRANSFORMATION AND DISAPPEARANCE OF THE POLITICAL QUESTION DOCTRINE
}

\author{
MARK TUSHNET
}

INTRODUCTION

I. BAKER V. CARR AND THE DOCTRINALIZATION OF THE

POLITICAL QUESTION DOCTRINE

II. STANDING AS A PRUDENTIAL APPROACH AND ITS

DOCTRINALIZATION ............................................................1214

III. THE SILENCES OF BUSH V. GORE ........................................1222

IV. BICKEL'S WORLD, AND OURS ..........................................1229

CONCLUSION. 1235

\section{INTRODUCTION}

Alexander Bickel and Fritz Scharpf treated the political question doctrine as one of the devices the Supreme Court could use in structuring the way it interacted with the overall political system. ${ }^{1}$ Bickel in particular conceded that the Court had to justify the decisions it made on the merits of constitutional questions by invoking principle. ${ }^{2}$ The problem with principle, as Bickel and

* Carmack Waterhouse Professor of Constitutional Law, Georgetown University Law Center. I would like to thank Rachel Barkow, Susan Low Bloch, Steve Goldberg, Heather Gerken, Vicki Jackson, and Louis Michael Seidman for their comments on drafts of this Essay.

1. Alexander M. Bickel, The Least Dangerous Branch: The Supreme COURT AT THE BAR OF POLITICS 183-97 (1962); Fritz W. Scharpf, Judicial Review and the Political Question: A Functional Analysis, 75 YALE L.J. 517, 517 (1966).

2. I use the term principle in the sense made familiar by Herbert Wechsler. Herbert Wechsler, Toward Neutral Principles of Constitutional Law, 73 HARV. L. REV. 1 passim (1959). Wechsler argued that our legal system accommodated the power of judicial review with democratic theory by insisting that judges exercise that power in a principled manner. By principled, Wechsler meant that judges had to deploy rules that were neutral in the sense that they did not systematically prefer one class of litigants to another except to the extent that the rules the judges invoked made the characteristics of the favored class relevant to the outcome. Id. at 15-16. For present purposes, I use a more modest and defensible definition: principle means that the Court has to decide by invoking a rule-like formulation that specifies the conditions under which one result rather than another follows. 
Scharpf saw it, was that invoking a rule might be imprudent, entangling the courts with the other institutions of the political system in ways that would not benefit the nation. ${ }^{3}$ The political question doctrine, along with other justiciability doctrines, provided the Court with techniques for refraining from deciding cases on the merits when doing so would be imprudent.

The difficulty with this analysis is that the political question doctrine is itself a rule, in the minimal sense that the Court has to provide reasons for invoking it. ${ }^{4}$ In providing reasons for invoking the doctrine, the Court creates a doctrine that inevitably undermines the possibility of deploying the political question doctrine in the service of prudent judgment, for it is precisely the characteristic of prudential judgment that cannot be captured in rules. Bickel thought that the political question doctrine "resists being domesticated." By that he meant that applying the doctrine inevitably required the courts to respond to prudential concerns that could not be reduced to rules, criteria, or even standards. He was wrong.

That, in short, is the story of Baker v. Carr. ${ }^{6}$ The Court treated the political question doctrine as a principle, as it had to within the framework accepted by the Justices, that constitutional decisions had to be principled. It thereby made the political question doctrine effectively unavailable as a technique for coordinating the Court with the nation's other political institutions. But, as Scharpf noted, the political question doctrine did serve important functions for the Court

3. As Louis Michael Seidman, the constitutional law scholar, has pointed out to me, for Bickel prudence might sometimes require the courts to refrain from acting because acting would require that they pursue principle when a principled decision-one compelled by law-would not benefit the nation.

4. Gerald Gunther's powerful criticism of Bickel's argument rested precisely on this insight, although Gunther phrased the point differently. Gerald Gunther, The Subtle Vices of the "Passive Virtues"-A Comment on Principle and Expediency in Judicial Review, 64 COLUM. L. REV. 1 passim (1964).

5. BICKEL, supra note 1 , at 125.

6. 369 U.S. 186 (1962).

7. Bickel's most effective arguments about prudence derived from his consideration not of the justiciability doctrine but of the Court's discretionary power to deny review. See, e.g., BICKEL, supra note 1, at 133-43. Translating those arguments to the context of doctrine proved impossible. And, even in the context of discretionary denials of review, dissents from refusals to review cases routinely describe rule- or standard-like considerations that the dissenters assert ought to govern the decision to review or not. Finally, it may be worth mentioning that the very fact that the Court granted review in the two 2000 election cases suggests that the Court sees a reduced role for prudential considerations even at the stage of granting review. 
and the nation. ${ }^{8}$ Not surprisingly, then, the concerns that made the political question doctrine attractive before Baker $v$. Carr remained important. Prudence simply migrated from the political question doctrine to the law of standing. But, once again, standing is a legal doctrine, and doctrinalization occurred again.

By the late 1990s, the justiciability doctrine had been thoroughly domesticated. Baker v. Carr gave us a list of criteria for deciding when to invoke the political question doctrine;" standing cases had developed the litany of "injury, causation, and redressability" to structure a purely doctrinal analysis. ${ }^{10}$ By the turn of the century, a complete transformation had occurred, as shown by the fact that only old-fashioned scholars noted what prior generations would have thought serious political question and standing problems in Bush v. Gore. ${ }^{11}$ This is a transformation of constitutional consciousness that can best be understood by historicizing the justiciability doctrines, that is, by trying to identify the historical circumstances under which those doctrines seemed appropriate vehicles for prudential judgments and the circumstances that led later constitutional thinkers to conclude that they were not such vehicles.

This Essay develops the foregoing argument by examining, in Section I, the transformation of the political question doctrine from Baker v. Carr through Walter Nixon v. United States. ${ }^{12}$ Section II charts a similar, perhaps even more dramatic transformation of the law of standing. ${ }^{13}$ Section III then examines Bush v. Gore, explaining how older doctrines of standing and political questions might have been thought relevant there. ${ }^{14}$ It argues as well that the very fact that those doctrines went unmentioned by the Court shows why we must take a historically grounded view of justiciability doctrines. Section IV sketches the historical settings in which the political question doctrine as a counsel of prudence arose and disappeared..$^{15}$ The Conclusion suggests that, in the current historical period, a practice of

8. Scharpf, supra note 1 , at $566-83$, identifies the bases of the political question doctrine to include functional reasons such as differential access to information and, important in the present context, the responsibilities of the political branches.

9. 369 U.S. 186, 217 (1962).

10. See, e.g., Allen v. Wright, 468 U.S. 737, 750-66 (1984) (denying standing to litigants who did not allege facts showing that they had suffered an injury that a judicial order would redress); Schlesinger v. Reservists Comm. to Stop the War, 418 U.S. 208, 21627 (1974) (denying standing to litigants who asserted only a generalized grievance).

11. 531 U.S. $98(2000)$.

12. 506 U.S. 224 (1993); infra notes 16-51 and accompanying text.

13. Infra notes $52-94$ and accompanying text.

14. Infra notes 95-124 and accompanying text.

15. Infra notes $125-50$ and accompanying text. 
judicial review constrained by prudence may be impossible to retrieve.

\section{BAKER V. CARR AND THE DOCTRINALIZATION OF THE POLITICAL QUESTION DOCTRINE}

I begin, boringly, by quoting the familiar catalogue of criteria Baker v. Carr discerned in the Court's political question cases:

[A] textually demonstrable constitutional commitment of the issue to a coordinate political department; or a lack of judicially discoverable and manageable standards for resolving it; or the impossibility of deciding without an initial policy determination of a kind clearly for nonjudicial discretion; or the impossibility of a court's undertaking independent resolution without expressing lack of the respect due coordinate branches of government; or an unusual need for unquestioning adherence to a political decision already made; or the potentiality of embarrassment from multifarious pronouncements by various departments on one question. ${ }^{16}$

Louis Henkin provided the definitive guide to understanding this catalogue in his challenge to the very existence of a political question doctrine. ${ }^{17}$ According to Henkin, most of the political question cases involved decisions by the Court (1) that the Constitution gave the political branches discretion to decide what to do and the political branches had not abused their discretion, or (2) that the Constitution placed no limits on the discretion of the political branches to decide what to do. ${ }^{18}$ Henkin's important point was that the Court's decisions are on the merits. That is, the Court in these cases interprets the Constitution to say one thing rather than another. Here Henkin drew on a thought in Baker v. Carr itself, arguing that no political question arises when all the Court must do is engage in ordinary constitutional interpretation. ${ }^{19}$

16. Baker v. Carr, 369 U.S. 186, 217 (1962).

17. Louis Henkin, Is There a "Political Question" Doctrine?, 85 YALE L.J. 597 passim (1976).

18. Id.

19. For completeness, I would add that there is a cluster of cases involving foreign affairs where the pull of some sort of political question doctrine seems strong. See, e.g., Japan Whaling Ass'n v. Am. Cetacean Soc'y, 478 U.S. 221, 230 (1986) (holding that "the challenge to the [Secretary of Commerce's] decision not to certify Japan for harvesting whales in excess of [International Whaling Commission] quotas presents a purely legal question of statutory interpretation" and thus the political question doctrine does not bar the Court's review of the decision); RICHARD FALLON ET AL., HART \& WECHSLER'S 
Henkin also identified an important residual category, which in my judgment provides the best explanation for whatever true political question doctrine there is: "there might be constitutional provisions which can properly be interpreted as wholly or in part 'selfmonitoring' and not the subject of judicial review."20 Understanding this suggestion requires that we resolve an ambiguity in Baker $v$. Carr's reference to a "constitutional commitment of the issue to a coordinate political branch." ${ }^{21}$ One possibility is that the "issue" is the question presented on the merits, where we want to know the right answer to a substantive constitutional question. The issue on the merits in Baker v. Carr was: Does the Constitution require some degree of equality in apportionments? Marbury $v$. Madison, saying that "[i]t is emphatically the province and duty of the judicial department to say what the law is, "22 strongly suggests that ordinary constitutional interpretation, done by the courts, tells us the answers to substantive constitutional questions.

For the political question doctrine to raise interesting questions about the Marbury tradition, the "issue" to which the Court refers must be different. For the political question doctrine, the "issue," in the Court's sense, is: Who gets to decide what the right answer to a substantive constitutional question is? Again, in Baker v. Carr, the issue in this sense, is: Who gets to decide whether the Constitution requires some degree of equality in apportionments? That is, the Court asks: Does the Constitution give a political branch the final power to interpret the Constitution? ${ }^{23}$

Self-monitoring provisions are those to which the answer is, Yes; this provision gives Congress or the President the final power to specify the meaning of the Constitution that the litigants have raised. I have argued elsewhere that self-monitoring constitutional provisions are those as to which we have some confidence that the political

THE FEDERAL COURTS AND THE FEDERAL SYSTEM 289-91 (4th ed. 1996) (describing the cases).

20. Henkin, supra note 17 , at $622-23$.

21. Baker, 369 U.S. at 217.

22. 5 U.S. (1 Cranch) 137,177 (1803).

23. In Baker, the question is: Does the Constitution give a political branch the final power to determine whether the Constitution requires some degree of equality in apportionments? In United States v. Munoz-Flores, 495 U.S. 385 (1990), the question was: Does the Constitution give Congress the ultimate authority to determine that a particular bill is indeed one "for raising revenue" that must originate in the House of Representatives? 
branches will do at least as good a job as the courts in interpreting the Constitution. ${ }^{24}$

We are now in a position to understand why the political question doctrine came under pressure once Baker v. Carr gave it the form of law. Baker v. Carr made it natural to reject political question arguments by noting that only an ordinary question of constitutional interpretation of the sort courts routinely answer was at stake. Notions of judicial supremacy make doubtful any assertion that a constitutional provision should be self-monitoring in Henkin's sense, while skepticism about the ability of the political branches to behave in a constitutionally responsible manner undermines the claim that any constitutional provision should be self-monitoring in the sense I have urged.

With this as background, I now review the Court's major political question cases from Baker to Walter Nixon. Baker itself, of course, asserted that the equal protection challenge it allowed to go forward presented an ordinary question of constitutional interpretation: "Judicial standards under the Equal Protection Clause are well developed and familiar...."25 The post-Baker reapportionment decisions illuminate what ordinary questions of constitutional interpretation are, even though the reapportionment decisions are not themselves political question decisions. ${ }^{26}$ The post-Baker judicial standards demonstrate judicial creativity in constitutional interpretation: If ordinary constitutional interpretation produces a quite rigid one-person, one-vote rule, what if anything lies outside the domain of ordinary constitutional interpretation?

The Court's answer is, "not much," when it rejects political question arguments. Powell v. McCormack ${ }^{27}$ is the paradigm. The House of Representatives refused to seat Adam Clayton Powell because he had been the subject of public scandals. ${ }^{28}$ Powell sought

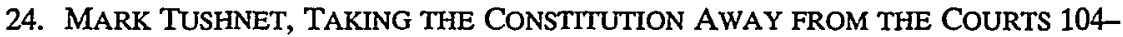
08 (1999).

25. Baker, 369 U.S. at 226.

26. See, e.g., Mahan v. Howell, 410 U.S. 315,324 (1973) (requiring a state to make an honest and good-faith effort to construct legislative districts of nearly equal population); Kirkpatrick v. Preisler, 394 U.S. 526, 530-32 (1969) (developing standards for determining when a deviation from one person, one vote is excessive); Avery v. Midland County, 390 U.S. 474, 476 (1968) (applying the one-person, one-vote rule to a county commission).

27. 395 U.S. 486 (1969); see also Japan Whaling Ass'n v. Am. Cetacean Soc'y, 478 U.S. 221, 230 (1986) (asserting that "under the Constitution, one of the Judiciary's characteristic roles is to interpret statutes, and we cannot shirk this responsibility merely because our decision may have significant political overtones").

28. Powell, 395 U.S. at 489-90 (referring to the House investigation of Representative Powell's financial dealings). 
judicial relief. The House officers he sued said that the Constitution gave the House the exclusive power "to Judge... the... Qualifications of its own Members."29 Powell said that this was a textual commitment only of the power to determine whether members satisfied the "qualifications" listed elsewhere in the Constitution. The Court agreed, holding that the House lacked power to refuse to seat a member who it conceded satisfied the enumerated qualifications. ${ }^{30}$ The analytic point is that the Court applies ordinary processes of interpretation to the clauses that a litigant claims commit the question to the political branches in deciding whether a question is a political question. Powell and the reapportionment cases following Baker $v$. Carr show how easy it is to interpret the clauses at issue in order not to commit the question to the political branches. ${ }^{31}$

United States v. Munoz-Flores ${ }^{32}$ has the same structure as Powell. The Victims of Crime Act contained a provision added in the Senate requiring people convicted of federal crimes to pay a special assessment to a Crime Victims Fund. Munoz-Flores said that the assessment violated the Constitution's requirement that "all Bills for raising Revenue shall originate in the House of Representatives. ${ }^{.33}$ The Court replied that Munoz-Flores could prevail only if the special assessment provision was a "Bill for raising Revenues."34 Determining what the Constitution meant when it referred to such bills was an ordinary question of constitutional interpretation. The Court then held that the Origination Clause did not refer to provisions aimed at funding particular programs, but only at bills that support general government programs.

The Court's only recent decision purporting to invoke the political question doctrine shows how hard it is to resist the pull of the argument that the Court can come up with a constitutional interpretation that answers what is said to be a political question, that

29. Powell, 395 U.S. at 513 (referring to U.S. CONST. art. I, § 5).

30. Id. at 550. The Court's confidence in its role is suggested by the fact that it reserved the question of whether it could review a decision by the House that a member did not satisfy one of the enumerated requirements. Id. at $521 \mathrm{n} .42$ ("[F]ederal courts might still be barred by the political question doctrine from reviewing the House's factual determination that a member did not meet one of the standing qualifications. This is an issue not presented in this case and we express no view as to its resolution.").

31. See also U.S. Dep't of Commerce v. Montana, 503 U.S. 442, 458-59 (1992) (rejecting a political question argument and finding justiciable a claim challenging Congress's choice of methods of apportioning seats among the states).

32. 495 U.S. 385 (1990).

33. U.S. CONST. art. I, $§ 7, \mathrm{cl} .1$.

34. Munoz-Flores, 495 U.S. at 387-88. 
is, one as to which the answer must come from the political branches. Walter Nixon v. United States ${ }^{35}$ involved Judge Nixon's challenge to the processes used in the Senate's impeachment trial that resulted in his conviction. Having found that conducting trials of impeachments before the entire Senate was, in the Senate's view, unduly burdensome, the Senate adopted a rule that allowed testimony to be presented before a committee, which would send to the entire Senate the transcript and a report summarizing the testimony. ${ }^{36}$ Under this procedure, not every Senator actually heard live witness testimony; the Senate's vote on whether to convict was based on the transcript and report. The relevant constitutional language is that the Senate has "the sole Power to try all Impeachments." 37 The term sole in this provision might seem to stand in Judge Nixon's way, but he relied on the proposition that the courts have the power to engage in ordinary constitutional interpretation. What the Constitution meant, Judge Nixon said, was that only the Senate-and no one else-could try him for the offenses with which he was charged. But, he argued, the Senate had to give him a trial, not some truncated proceeding: True, the Senate has the sole power to try him, but it has to try him.

The Court seemed to hold that Judge Nixon's claim presented a political question, concluding that "the word 'try' in the Impeachment Trial Clause does not provide an identifiable textual limit on the authority which is committed to the Senate."38 Justice White's concurring opinion pointed out difficulties with that conclusion. His example was this: No one would contend that the Senate had given a judge a trial in any sense whatever if it followed a "practice of automatically entering a judgment of conviction whenever articles of impeachment were delivered from the House." 39 As Justice White put it, in terms that recall the aftermath of Baker v. Carr, "try' presents no greater, and perhaps fewer, interpretive difficulties than some other constitutional standards that have been found amenable to familiar techniques of judicial construction." ${ }^{20} \mathrm{He}$ conceded that his example involved an improbable hypothetical case, but emphasized that, as long as the courts were able to say that something was not a trial, the word "try" had a meaning the courts could discern.

35. 506 U.S. 224 (1993).

36. See id. at 227 n.1 (quoting the Senate rule).

37. U.S. CONST. art. I, $\$ 3$, cl. 6 .

38. Walter Nixon, 506 U.S. at 238.

39. Id. at $246-47$ (White, J., concurring in the judgment).

40. Id. at 247 (White, J., concurring in the judgment) (emphasis added). 
And, as it happens, elements of the Court's opinion seem to agree with Justice White. The Court noted that "[ $t]$ he word 'try,' both in 1787 and later, has considerably broader meanings than those to which [Judge Nixon] would limit it."41 That observation comes close to rejecting on the merits Judge Nixon's claim that he had not received a trial within the meaning of the Impeachment Clause. As Henkin noted, some cases described as posing political questions actually involve only the question of whether the political branches abused a discretion given them by the Constitution. ${ }^{42}$ Justice White would have interpreted the Constitution to give the Senate substantial discretion to specify trial procedures, that is, to pin down in detail what the word try meant. But, Justice White said, and the Court's discussion of the broad meanings of the word seems to agree, that even though the Senate was given wide latitude in specifying trial procedures, the courts are not precluded from deciding that the Senate had abused the discretion the Constitution gave them to define terms. ${ }^{43}$

The Court engages in the interpretive enterprise all the time. Though nominally holding that the case presented a political question, Walter Nixon shows how difficult it is for the Justices to assert unqualifiedly that a particular constitutional provision really has no meaning the Court can identify. And, in a world where the Court is comfortable with interpreting the Constitution and uncomfortable with allowing anyone else to do so, once it is conceded that a provision means something, the "textually demonstrable commitment" element simply falls away.

Goldwater v. Carter, ${ }^{44}$ the only other recent case in which the political question doctrine figured prominently, illustrates the problem as well. The United States and the Republic of China, located in Taiwan, had a mutual defense treaty, which the Senate had ratified. The People's Republic of China insisted that the United States abrogate the treaty if the United States and the People's Republic were to have diplomatic relations. Acting without the participation of the Senate, President Jimmy Carter announced that

41. Id. at 229.

42. Henkin, supra note 17.

43. See also id. at 254 (Souter, J., concurring in the judgment) (asserting that the courts would have a role if "the Senate's action [was] ... so far beyond the scope of its constitutional authority ... as to merit a judicial response").

44. 444 U.S. 996 (1979). The case also indicates the pull of the foreign affairs context on the political question doctrine. But see Japan Whaling Ass'n v. Am. Cetacean Soc'y, 478 U.S. 221, 229-30 (1986) (rejecting the argument that the foreign affairs context of a statutory interpretation case should limit the Court's role). 
the United States would abrogate the mutual defense treaty. Senator Barry Goldwater challenged the abrogation, arguing that the Constitution, in giving the Senate a role in creating treaties, also gave it a role in abrogating them: the Constitution expressly said that Senate agreement was necessary to enter into a treaty relation, and, Senator Goldwater asserted, the Constitution should be interpreted to require Senate agreement to get out of a treaty relation.

The Supreme Court ultimately rejected Senator Goldwater's claim, with the Justices expressing a variety of views on why he should not prevail. For present purposes, the position of then-Justice Rehnquist, and the responses of Justices Brennan and Powell, are the most important. Justice Rehnquist and three others found that Senator Goldwater's claim raised a political question. ${ }^{45}$ In part that was because of the foreign affairs setting. But, in addition, Justice Rehnquist said that the Constitution committed the question of who must participate in a treaty abrogation to the political branches ${ }^{46}$ His argument was that the Constitution expressly said that the Senate had to participate in creating a treaty relation, and that, in saying nothing about whether it had to participate in abrogating such a relation, the Constitution implicitly left that question to the political branches to resolve: "[W]hile the Constitution is express as to the manner in which the Senate shall participate in the ratification of a treaty, it is silent as to that body's participation in the abrogation of a treaty. ${ }^{\prime 47}$ Silence meant that the question was left to the political branches.

Justice Powell also did not reach the merits, believing that Senator Goldwater's claim was not ripe, but he disagreed with Justice Rehnquist's analysis. Justice Powell posed the following problem: "Assume that the President signed a mutual defense treaty with a foreign country and announced that it would go into effect despite its rejection by the Senate. Under Mr. Justice Rehnquist's analysis that situation would present a political question even though Art. II, §2, clearly would resolve the dispute."148 But Justice Powell said, the "legal issue" presented by a unilateral presidential commitment to a treaty relation was no different from the legal issue presented by a unilateral presidential decision to end such a relation: "In both cases, the Court would interpret the Constitution to decide whether congressional approval is necessary to give a Presidential decision on

45. Goldwater, 444 U.S. at 1002-06 (Rehnquist, J., concurring in the judgment).

46. Id. at 1002-04 (Rehnquist, J., concurring in the judgment).

47. Id. at 1003 (Rehnquist, J., concurring in the judgment).

48. Id. at 999-1000 (Powell, J., concurring in the judgment). 
the validity of a treaty the force of law." ${ }^{49}$ The only difference, to Justice Powell, was that his hypothesized case presented "textual" analysis while Senator Goldwater's real one required "interstitial analysis," that is, interpretation based on inferences from what the Constitution said and what it did not say. Interstitial analysis, to Justice Powell, was, like textual analysis, an exercise in ordinary constitutional interpretation.

In reviewing this history, we see that the overall effect of Baker v. Carr was what I have referred to as the doctrinalization of the political question doctrine. The Court converted into a set of legal rules an approach that had some flexibility and that therefore might be invoked whenever a majority thought that the prudent course was to avoid involvement in a constitutional dispute. Baker v. Carr specified six elements of the doctrine and came to be understood as insisting that at least one be present when the Court finds a case to raise a political question. ${ }^{50}$ Even more, the Court has not invoked the more obviously flexible criteria articulated in Baker v. Carr-the last four of the six on its list-in any recent case, to the point where it seems fair to say that the only real components of the doctrine are the first two: a textually demonstrable commitment to the political branches and the lack of judicially manageable standards. ${ }^{51}$

As Bickel understood, however, prudent judgment cannot be captured in rules. If, as Scharpf emphasized, techniques of avoiding a decision for prudential reasons were functional for the Court, Baker v. Carr's elimination of one such technique might compel the Court to find another. For a while, the Court settled on the doctrine of standing, but it too lost its functional value as an avoidance device as it became doctrinalized. By the time that happened, the functional need for avoidance doctrines disappeared.

49. Id. (Powell, J., concurring in the judgment).

50. See ERWIN ChEMERINSKY, CONSTITUTIONAL LAW: PRINCIPLES AND Policies 119 (1997) ("Virtually every case considering the political question doctrine quotes [the list of six factors]."). For the factors, see supra text accompanying note 16.

51. The Court has not explicitly reduced the doctrine to these two components, and presumably the other four remain available in the event that the Court chooses to revive a more discretionary doctrine than the one it has recently invoked. Still, it seems worth noting that it would not have been difficult to say that deciding the merits of the question presented in Powell v. McCormack would express a lack of respect for the House of Representatives, and yet the Court did not do so. 


\section{STANDING AS A PRUDENTIAL APPROACH AND ITS DOCTRINALIZATION}

Although sounding some prudential themes, Flast v. Cohen initiated the doctrinalization of standing law. ${ }^{52}$ The standing doctrine's potential to replace the political question doctrine was apparent in the Court's assertion that the Constitution's "case or controversy" language "define[s] the role assigned to the judiciary in a tripartite allocation of power to assure that the federal courts will not intrude into areas committed to the other branches of government."53 Justice Powell's observation in a case about standing, that justiciability doctrines were "founded in concern about the proper-and properly limited-role of the courts in a democratic society," is to the same effect..$^{54}$

A series of cases involving what the Court called "generalized grievances" blurred the lines between standing law and the political question doctrine. ${ }^{55}$ United States $v$. Richardson denied standing to taxpayers who challenged Congress's failure to disclose the budgets of several national security agencies as a violation of the Constitution's requirement that "a regular Statement and Account of the Receipts and Expenditures of all public Money shall be published from time to time." ${ }^{56}$ After saying that the plaintiffs lacked standing because they presented only a generalized grievance shared by every taxpayer, the Court concluded:

It can be argued that if respondent is not permitted to litigate this issue, no one can do so. In a very real sense, the absence of any particular individual or class to litigate these claims gives support to the argument that the subject matter is committed to the surveillance of Congress, and ultimately to the political process. ${ }^{57}$

This comes very close to asserting that the question presented was a political one.

As a law of standing developed, the possibility of deploying it in the service of prudent judgment disappeared, to be replaced by a doctrinalized concern about congressional interference with the

52. 392 U.S. 83, 105-06 (1968) (holding that taxpayers have standing to invoke federal jurisdiction where they allege that tax money is spent in violation of constitutional restraints on legislative power).

53. Id. at 95 .

54. Warth v. Seldin, 422 U.S. 490,498 (1975).

55. See, e.g., United States v. Richardson, 418 U.S. 166, 175 (1974).

56. Id. at $167-70$ (citing U.S. CONST. art I, § 9, cl. 7).

57. Id. at 179. 
executive's discretion to choose how to enforce the law. Standing doctrine, that is, was transformed from something allowing the courts to express a generalized concern about their role into a doctrine about the division of power between Congress and the President.

The Court might have developed Flast $v$. Cohen in a way that would have eliminated the standing doctrine entirely. It quoted Baker v. Carr for its central proposition that standing required only that the litigant have "such a personal stake in the outcome of the controversy as to assure that concrete adverseness which sharpens the presentation of issues upon which the court so largely depends for illumination of difficult constitutional questions." 58 As scholars noted, no one seriously pursues expensive litigation without doing the best to present the strongest arguments to illuminate the questions presented.99 Were "concrete adverseness" the governing standard, only quirky cases presented by pro se litigants would be dismissed on standing grounds.

Perhaps because the Warren Court did not get a chance to push its standing doctrine to maturity due to the fact Flast was decided shortly before President Nixon's appointments transformed the Court, the Court tried to define tests for identifying when concrete adverseness existed. A shorthand summary of the modern test is that standing law requires that a litigant have suffered a harm of a type the courts are willing to acknowledge to be a harm, caused by unconstitutional actions taken by the government defendants, and likely to be eliminated or at least alleviated by some remedy the courts are in a position to award. ${ }^{60}$

The law of cognizable harm developed along two tracks. In terms of timing, the Court, influenced by the economic regulatory programs associated with the New Deal, initially thought that identifying cognizable harms was an essentially judicial task, albeit sometimes with guidance from Congress. ${ }^{61}$ The Court rethought its position as the Great Society Congresses enacted environmental and consumer-oriented programs. The Court concluded that Congress

58. Flast, 392 U.S. at 99 (quoting Baker v. Carr, 369 U.S. 186, 204 (1962)).

59. See, e.g., Kenneth E. Scott, Standing in the Supreme Court: A Functional Analysis, 86 HARV. L. REV. 645, 674 (1973) (discussing the high costs of litigation to individual plaintiffs as a deterrent against suits in which a plaintiff has no stake).

60. In what follows I focus on the problem of determining what are cognizable harms; the contours of developments regarding causation and redressability are essentially the same as the ones I describe with respect to harm.

61. See, e.g., FCC v. Sanders Bros. Radio Station, 309 U.S. 470, 475 (1940) (allowing a competitor to challenge a grant of a radio license on the ground that the license did not serve the public interest). 
had a large role in specifying constitutionally cognizable harm. ${ }^{62}$ Ultimately, the only constraint the Court recognized on Congress's power to specify harms that give rise to standing was based on Article II, not Article III. ${ }^{63}$ Once that recognition occurred, the cases involving judicial identification of cognizable harm could be seen in a new light. They became cases in which standing would exist had Congress conferred it. But, in the absence of congressional action, the courts would say, in effect, "The injury you say you have suffered simply does not count with us, even though it might be an injury in some sense." And, in saying that, the courts necessarily decided that the Constitution provided no remedy for that kind of injury. The decisions, that is, were on the merits of the constitutional claims presented.

To the extent that the courts had a doctrine of standing before the New Deal, that doctrine required plaintiffs to allege that they were injured in a way closely analogous to the injuries remedied in traditional common law actions. ${ }^{64}$ The government had to do something that the courts saw as resembling a trespass onto the plaintiff's land, for example. The rise of the administrative state placed this notion of harm under such pressure that it simply disappeared. FCC v. Sanders Bros. Radio Station ${ }^{65}$ is usually cited as the case where the Court abandoned the requirement of commonlaw-like injury. The radio station sought judicial review of an FCC decision awarding a broadcast license to a competitor. The radio station had no right to be free from competition, but, the Court held, it could assert the general public interest in radio station licensing. Sanders Bros. highlighted the legal realist point that harm was not a category that existed in the natural world. It was, rather, a category created by law. Congress might identify special harms that the courts would not, but the conceptual underpinnings of Sanders Bros. showed that decisions, whether by Congress or by the courts, treating some things as harms and others not as harms were exercises of law-making power.

62. See, e.g., Sierra Club v. Morton, 405 U.S. 727, 734-41 (1972) (denying standing in the particular case, but acknowledging that esthetic, conservation, or recreational harm could support standing).

63. See infra text accompanying notes 71-73.

64. See GEOFFREY R. STONE ET AL., CONSTITUTIONAL LAW 101 (4th ed. 2001) ("In the early days of standing doctrine - the first decades of the twentieth century-a common law interest was often treated as a necessary basis for standing.").

65. 309 U.S. 470 (1940). 
The critical development came when the Court recognized that Congress could actually create interests, the infringement of which would cause constitutionally cognizable harm. ${ }^{66}$ Classical environmental law protected people against nuisances, which were readily assimilated to common law trespass; modern environmental law protected people against injuries to their esthetic interests, which had no obvious common law analogues. The Freedom of Information Act gave everyone an interest in access to government information, an interest for which there was no obvious common law analogue. Racial discrimination was similar to classical harms; refusing to show available apartments to racial "testers" who had no interest in renting was not. ${ }^{67}$ The Court conceptualized the testers' interest as one in acquiring information. It knew, of course, that such an interest arose not from anything analogous to practices causing common law harms but simply from the fact that Congress wanted information about apartments distributed without regard to race.

The Court's decisions restricting standing in the modern era are to some extent misleading. With respect to harm, their sole focus was whether the particular plaintiff had in fact suffered harm to an interest created by Congress. The most dramatic example of this phenomenon is Lujan v. Defenders of Wildlife. ${ }^{68}$ The case involved a challenge to a rule interpreting the Endangered Species Act to apply only to projects within the United States or on the high seas. The plaintiffs were environmentalists whose affidavits alleged that they had traveled abroad, and intended to continue such travel, to view endangered species whose habitats were threatened by projects receiving support from the U.S. government. A majority of the Court found that the plaintiffs had not alleged that they would be harmed by the failure to apply the Act to those projects. ${ }^{69}$ But, it turned out, the problem was that the plaintiffs said only that they hoped to travel abroad in the future. A majority of the Justices indicated that the plaintiffs would have had standing if they had had concrete plans to engage in that travel. As many have observed, a law of standing that

66. See Linda R.S. v. Richard D., 410 U.S. 614, 617 n.3 (1973) ("Congress may enact statutes creating legal rights, the invasion of which creates standing, even though no injury would exist without the statute.").

67. Havens Realty Corp. v. Coleman, 455 U.S. 363, 372-80 (1982) (finding standing for an African-American "tester" who had no interest in renting but who had received discriminatory misrepresentations, where Congress had acted to assure that representations about apartment availability would be made in a nondiscriminatory way).

68. 504 U.S. 555 (1992).

69. Id. at $562-64$. 
can be satisfied by buying a ticket to fly to Egypt is not doing much serious work. ${ }^{70}$

The plaintiffs in Lujan also sought standing under a citizen-suit provision allowing "any person" to bring suit. They argued that the provision gave standing because it created an interest in seeing that the law was obeyed. ${ }^{71}$ More important for present purposes, they argued that the cases acknowledging congressional power to create interests that, if infringed, gave rise to standing allowed Congress to create precisely the interest in seeing the law obeyed. The Court invoked the principle barring courts from hearing cases that present only generalized grievances to dismiss this claim. It acknowledged that the prior cases had not involved claims based on statutory provisions giving anyone a right to sue, but denied that that distinction mattered. It continued,

Vindicating the public interest ... is the function of Congress and the Chief Executive.... To permit Congress to convert the undifferentiated public interest in executive officers' compliance with the law into an "individual right" vindicable in the courts is to permit Congress to transfer from the President to the courts the Chief Executive's most important constitutional duty, to "take Care that the Laws be faithfully executed."72

With this, standing shifted from Article III to Article II, at least when a litigant relied on a congressional statute purporting to confer standing. ${ }^{73}$

Federal Elections Commission v. Akins ${ }^{74}$ seems to transform the generalized grievance rule. A Federal Election Campaign Act provision broadly allowed "any party" who thought the Commission

70. See, e.g., Cass R. Sunstein, What's Standing After Lujan? Of Citizen Suits, "Injuries," and Article III, 91 MICH. L. REV. 163 (1992).

71. Id. at 576-77.

72. Id. at 576 (quoting U.S. CONST. Art II, § 3).

73. But see Raines v. Byrd, 521 U.S. 811, 813 (1997) (applying general standing doctrine without discussing the fact that a statute may have specifically conferred standing). There the Court denied standing to a member of Congress challenging the Line Item Veto Act because Congress's members did not have a sufficient personal stake in the dispute and did not allege a sufficiently concrete injury. The statute authorized suit by "[a]ny Member of Congress or any individual adversely affected" by the Act, 2 U.S.C. $\S 692$ (a)(1) (2000). The Court appears to have read this provision as requiring that the members of Congress authorized to sue must be adversely affected as the Court had traditionally interpreted that phrase. This is not the most natural reading of the provision, because it makes the reference to members of Congress redundant (a member of Congress adversely affected is necessarily an individual adversely affected).

74. 524 U.S. 11 (1998). 
erred in dismissing a complaint to seek judicial review. ${ }^{75}$ The plaintiffs thought the Commission had committed legal error in failing to require a political action committee to disclose information that the statute required to be disclosed. The Court agreed that the plaintiffs had standing. It said that the Commission's "strongest argument is its contention that this lawsuit involves only a 'generalized grievance." "76 The Court said that its prior cases invoking the generalized grievance rule involved what the Court called "abstract and indefinite" harms that were also widely shared." "The abstract nature of the harm ... deprives the case of the concrete specificity" that Article III requires. ${ }^{78}$ It contrasted such harms with widely shared harms that are "concrete." Informational injury, that is, the deprivation of access to information that Congress wanted available, was a widely-indeed, I would think, universally-shared concrete harm, whereas the "interest in seeing that the law is obeyed" was a widely, indeed perhaps universally, shared abstract harm.

The distinction between widely shared abstract harms and widely shared concrete ones remains undeveloped and unclear. Still, take the rule that standing exists when a plaintiff alleges a widely shared concrete harm to an interest Congress wanted to protect, join it with the rule that plaintiffs can show individualized harm to such interests by careful pleading, and we have a law of standing that comes close to requiring the minimal concrete adverseness that Flast v. Cohen identified as the constitutional requirement.

Some qualifications are necessary. First, the concrete adverseness requirement probably still does screen out the frivolous pro se litigant. Second, standing law now has an Article II basis ${ }^{79}$ but only when the litigant challenges actions by federal executive officials, a much smaller class of cases than the one to which earlier standing doctrine applied. Third, as the Court in Akins said, the fact that an injury is widely shared might "counsel[] against ... interpreting a statute as conferring standing." 80 So, to the extent that standing law is not Article II law, it is now a law about rules of statutory interpretation.

75. 2 U.S.C. $\$ 437(\mathrm{~g})(\mathrm{a})(8)(\mathrm{A})(2000)$.

76. Akins, 524 U.S. at 23.

77. Id.

78. Id. at 24.

79. See Lujan v. Defenders of Wildlife, 504 U.S. 555, 577 (1992) (disallowing Congress to permit individual citizens to sue executive officials in order to see that the laws are properly executed); see also supra notes 60-63 and accompanying text.

80. Akins, 524 U.S. at 24. 
After the Court acknowledged broad congressional power to identify constitutionally cognizable harms, limited only by Article II, judicial decisions about which harms gave rise to standing and which did not became transparently decisions on the merits, rather than decisions about some question prior to the merits. Northeastern Florida General Contractors v. Jacksonville, ${ }^{81}$ read against the background of Allen v. Wright, ${ }^{82}$ demonstrates the inseparability of the merits from the supposedly antecedent question of harm. The Internal Revenue Code allows private schools to obtain tax exempt status, but only if they do not discriminate on the basis of race. ${ }^{83}$ Allen $v$. Wright rejected a challenge to the methods the Internal Revenue Service ("IRS"), constrained by congressional dictates, used to determine whether private schools receiving such exemptions were in fact operating without racial discrimination. ${ }^{84}$ The parents of African-American school children, who alleged that the assertedly feeble IRS enforcement program violated their constitutional rights, brought the challenge. The Court held that the plaintiffs did not have standing..$^{85}$

Allen v. Wright contained several themes. One touched on Article II concerns: The Court noted the principle " that the Government has traditionally been granted the widest latitude in the "dispatch of its own internal affairs." "\$6 It cited Article II in support of its observation that the principle, "[w]hen transported into the Art. III context, ... counsels against recognizing standing in a case brought ... to seek a restructuring of the apparatus established by the Executive Branch to fulfill its legal obligations." ${ }^{87} \mathrm{My}$ present concern is with the way in which the Court dealt with one of the alleged harms, characterized by the Court as a claim of stigmatic injury. That is, the plaintiffs said that the IRS's feeble enforcement effort communicated a message to them and others that the interests of African Americans in reducing discrimination were not worth serious consideration. The Court said that this did not "constitute

81. 508 U.S. $656(1993)$.

82. 468 U.S. 737 (1984).

83. 26 U.S.C. \$ 501(c)(3) (2000); see Bob Jones Univ. v. United States, 461 U.S. 574, 598-99 (1983) (holding that a racially discriminatory private school was not entitled to taxexempt status as a charitable institution).

84. Allen, 468 U.S. at $739-40$.

85. Id. at 740 .

86. Id. at 761 (quoting Rizzo v. Goode, 423 U.S. 362, 378-79 (1976) (quoting Cafeteria Workers v. McElroy, 367 U.S. 886, 896 (1961))).

87. Id. 
judicially cognizable injury." " The Court in Allen $v$. Wright tried to explain why it should not recognize stigmatic injury as a constitutionally cognizable harm: "A black person in Hawaii could challenge the grant of a tax exemption to a racially discriminatory school in Maine." 89 Stigmatic injury, that is, was a generalized grievance, and the law of standing precluded courts from hearing cases resting on generalized grievances.

In Northeastern Florida General Contractors, ${ }^{90}$ the plaintiffs were a group of contractors who challenged a local affirmative action program that set aside a portion of city contracts for minority contractors. ${ }^{91}$ The court of appeals denied standing because none of the plaintiffs alleged that it would have been awarded a contract had there been no set-aside program. ${ }^{92}$ The Supreme Court reversed, saying that the contractors' injury was the denial of an opportunity to compete on an equal footing, not denial of the contracts themselves. ${ }^{93}$

Taken together, Allen and Northeastern illustrate that denial of an opportunity, even if having the opportunity would not eventuate in any material benefit to the plaintiff, is a judicially cognizable injury, while suffering from communications by the government that devalue one's race-based concerns is not. This conclusion suggests that the courts recognize injuries pretty much by fiat: This one counts, that one does not. Or, more precisely, as a matter of substantive constitutional interpretation, the Constitution does not protect African Americans against stigmatic injury, while it does protect against denials of opportunity to compete on an equal basis. One can defend both of those conclusions in substantive constitutional terms, but the defense would operate on the level of substance, not on the level of standing to sue. Further, if the problem in Allen was that the

88. Id. at 753 .

89. Id. at 756.

90. Northeastern Fla. Chapter of Associated Contractors of Am. v. City of Jacksonville, 508 U.S. 656 (1993).

91. Id. at 659 (describing the plaintiffs as not qualifying as "Minority Business Enterprises" under the Jacksonville ordinance).

92. Northeastern Fla. Chapter of Associated Contractors of Am. v. City of Jacksonville, 951 F.2d 1217, 1219 (11th Cir. 1992).

93. City of Jacksonville, 508 U.S. at 666 . The Court wrote:

When the government erects a barrier that makes it more difficult for members of one group to obtain a benefit than it is for members of another group, a member of the former group seeking to challenge the barrier need not allege that he would have obtained the benefit but for the barrier in order to establish standing. The "injury in fact" in an equal protection case of this variety is the denial of equal treatment resulting from the imposition of the barrier, not the ultimate inability to obtain the benefit. 
case presented only a generalized grievance, it is hardly obvious that one can consistently assert both that stigmatic injury suffered, on the Allen litigants' theory, only by African Americans, is a generalized grievance and that denial of the opportunity to compete on an equal basis suffered in Northeastern Florida Contractors by all non-minority contractors is not. ${ }^{94}$

Even if one can distinguish between Allen and Northeastern Florida Contractors in some way that does not ultimately define injury with reference to the merits of the constitutional claim, other difficulties remain. The Court's recognition of congressional power to create standing in large classes of citizens-in effect, to make generalized grievances justiciable-is in tension with the notion that the Constitution relegates the resolution of generalized grievances to Congress. Because Congress has the power to confer standing, the only real question in any standing case should be whether Congress has done so-that is, how the courts should interpret the statutes under which they act.

The rule from the Court's cases, then, is that the Constitution requires something other than an assertion of a generalized grievance. Thus, Congress can resolve the problem, unless Congress wants the courts to resolve it, in which case the Constitution requires the courts to do Congress's bidding, unless doing so would interfere with the President's duty to execute the laws. The law of standing, once fully doctrinalized, becomes a combination of a narrow Article II-based rule and some presumptions about how to interpret statutes. As with the political question doctrine, the law of standing can no longer be the vehicle for the expression of prudential judgments about when the courts might properly participate in resolving questions about the overall operation of our system of government.

\section{THE SILENCES OF BUSH V. GORE}

Judicial conservatives of a prior generation would at least have worried about the justiciability of the challenges raised in Bush v. Gore. They would have noticed standing and political question problems in the case. What accounts for the striking silences about those problems in the Court's opinion finding an equal protection

94. Perhaps the distinction introduced in Akins between abstract and concrete generalized grievances might be developed in a way that shows why a stigmatic injury is abstract while the denial of the opportunity to compete on an equal basis is concrete. What that account might be, however, is unclear to me; stigmatic injury seems to me fairly described as concrete. 
violation and in the opinion for the three Justices finding a violation of Article II?

The facts of Bush v. Gore need no restating..$^{95}$ A majority of the Supreme Court held that the system devised by the Florida Supreme Court violated principles of equal protection. ${ }^{96}$ The standing problem is this: ${ }^{97}$ We can identify two equal protection problems that might arise from the recounting system. First, the system might have been skewed, intentionally or otherwise, to favor Vice President Gore by making it more likely that new votes for him would turn up than would new votes for Governor Bush. On this theory the equal protection problem is a straight-forward one of partisan vote dilution. Either Governor Bush or a Florida voter who voted for Governor Bush would clearly have standing.

Unfortunately, that is not the theory the Court adopted. Instead, the Court said that the constitutional violation occurred because the recount system did not guarantee that ballots cast by voters in different precincts that either were identical in physical appearance or otherwise equally reflected a clear voter intent would be given identical treatment (whether counted or cast aside). Why should Governor Bush have standing to raise this claim? One thing should be obvious: Governor Bush cannot assert standing on the ground that the constitutional flaw in the recount system adversely affected him. The flaw identified by the Supreme Court majority has no systematic relationship to votes for either candidate: On the Court's analysis, a recount conducted under the Florida court's system might have produced more votes for Governor Bush, not Vice President Gore. ${ }^{98}$

95. 531 U.S. $98(2000)$.

96. Id. at 106 ("The want of those rules here has led to unequal evaluation of ballots in various respects.").

97. For a more complete analysis, see Pamela S. Karlan, The Newest Equal Protection: Regressive Doctrine on a Changeable Court, in THE VOTE: BUSH, GORE, \& THE SUPREME COURT 77-97 (Cass R. Sunstein \& Richard A. Epstein eds., 2001) (discussing how the Court's equal protection analysis in Bush v. Gore and recent cases indicates skepticism for Congress's motives and competence) [hereinafter Karlan, Newest Equal Protection]; Pamela S. Karlan, Nothing Personal: The Evolution of the Newest Equal Protection from Shaw v. Reno to Bush v. Gore, 79 N.C. L. REV. 1345, 1356-66 (2001) (analyzing the standing of individual Florida voters as well as the candidates for President in the 2000 presidential race in light of wrongful districting standing decisions).

98. Perhaps we might defend the Court's rule as a prophylactic one guarding against partisan vote dilution that is difficult to detect. If so, a person claiming to have been the victim of partisan vote dilution would have standing to raise the equal protection claim the Court recognized. 
A more plausible argument about standing is also more complex. On the Supreme Court's analysis, we know that there is a group of voters whose votes might not be counted when physically identical ballots were counted. It would be a miracle if no Bush voters were among that group. But no individual Bush voter can confidently assert that her ballot would not be counted. Governor Bush might then have third-party standing to assert the interests of the Bush voters among the group disadvantaged by the recount system. Equally, of course, Vice President Gore would have standing to assert the interests of the Gore voters in that group. This leads one to wonder whether, with respect to the constitutional violation the Court actually found, the case should have been seen as non-adversarial. ${ }^{99}$

An even more plausible argument for standing exists. Richard Pildes has identified a distinct form of injury associated with certain voting systems, which he says work expressive harm. ${ }^{100}$ Pildes developed the concept to deal with the problems of finding standing under traditional notions of injury in cases involving race-conscious districting. ${ }^{101}$ Pamela Karlan has suggested that Bush v. Gore also involves this sort of harm, worked by a flaw in the election process of a sort that does not generate identifiable individuals who have suffered from having their votes diluted or otherwise devalued. ${ }^{102}$

Pildes and Karlan point out that anyone within a jurisdiction operating a voting system that implicates expressive discrimination has standing to raise the objection. ${ }^{103}$ That idea, however, raises another problem. As we have seen, the Court has said that the very fact that anyone can raise a particular constitutional claim is a reason for denying standing to all. ${ }^{104}$ Standing so broadly available demonstrates that the plaintiff has a generalized grievance better

99. Perhaps we might develop an idea of "pendent" standing, which would operate like this: A litigant clearly has standing to raise legal argument $X$, but the court rejects that argument while accepting another argument $Y$, which the litigant would not otherwise have standing to raise. Pendent standing allows the court to enter a judgment predicated on argument $Y$ even though it would not have been able to do so had the litigant raised only argument $Y$ in the complaint.

100. Richard H. Pildes \& Richard G. Niemi, Expressive Harms, "Bizarre Districts," and Voting Rights: Evaluating Election-District Appearances After Shaw v. Reno, 92 MICH. L. REV. 483, 486 (1993) (arguing that "district appearance claims" work "expressive harms" rather than material harms because they center on the perceived legitimacy of structures of political representation instead of on the distribution of power between political groups).

101. Id. at 513-16.

102. Karlan, Newest Equal Protection, supra note 97, at 1356-64.

103. Once again, this approach suggests that the litigation on the legal issue the Court accepted in Bush v. Gore was nonadversarial.

104. See supra notes 55-59 and accompanying text. 
addressed through the political process than through constitutional adjudication. ${ }^{105}$

The answer to this objection, if there is one, comes from Baker $v$. Carr itself. It is that equal protection claims of any sort, including claims of expressive harm, are justiciable. To quote the key passage from Baker v. Carr again, "Judicial standards under the Equal Protection Clause are well developed and familiar."106 The Bush v. Gore Court's reluctance to commit itself to any equal protection doctrine casts some shadows on an approach that would allow standing in anyone to raise any equal protection claim, ${ }^{107}$ but Baker $v$. Carr, supplemented by later voting discrimination cases, at least provides some basis for finding standing in Bush v. Gore.

No one would today contend that the equal protection claim in Bush v. Gore raised a political question. The argument accepted by three Justices in their concurring opinion that the Florida Supreme Court's action violated Article II is another matter. ${ }^{108}$ The argument they accepted was that the Florida Supreme Court's interpretation of the Florida statutes regulating elections and recounts was so eccentric as to amount to a judicial displacement of the power committed by the Constitution to the state legislature to direct how presidential electors are to be appointed. But, critics suggest, the Constitution

105. I have been discussing who might have standing, at the outset, to raise the equal protection claim the Court recognized. Perhaps, however, the only relevant question is whether Governor Bush had standing at the Supreme Court level. (State courts need not restrict standing to litigants who satisfy the federal Article III standards.) There, he could claim that the Florida Supreme Court's action deprived him of a victory; that is, his claim would not be against anything associated with the recount, but would be against the Florida Supreme Court's decision. Cf. ASARCO, Inc. v. Kadish, 490 U.S. 605, 624 (1989) (finding that litigants who might not have had Article III standing nonetheless had standing to raise, in the Supreme Court, the claim that the appealed state court decision itself injured them; Chief Justice Rehnquist and Justice Scalia dissented on this issue, and Justice O'Connor did not participate in the decision).

106. Baker v. Carr, 369 U.S. 186, 226 (1962). Erwin Chemerinsky argues that Baker v. Carr found justiciability not for all equal protection claims associated with elections, but only for cases claiming malapportionment. Erwin Chemerinsky, Bush v. Gore Was Not Justiciable, 76 NOTRE DAME L. REV. 1093, 1108 (2001).

107. Bush v. Gore, 531 U.S. 98, 109 (2000) ("Our consideration is limited to the present circumstances, for the problem of equal protection in election processes generally presents many complexities.").

108. For a more complete analysis of the political question issue, see Samuel Issacharoff, Political Judgments, in THE VOTE: BUSH, GORE, \& THE SUPREME COURT, supra note 97 , at 55 . 
committed the decision about whether there had been such a displacement to Congress. ${ }^{109}$

There appears to be an emerging consensus that the Article II issue in Bush v. Gore was indeed a political question. ${ }^{110}$ The relevant clauses are in the Twelfth Amendment. Much in the argument for the proposition that the Article II issue presented a political question turns on what I call the atmospherics of the Twelfth Amendment. Reading the Amendment, one certainly gets the general impression that Congress was supposed to play a large, and perhaps the only, role in resolving contested presidential elections. Certainly nothing in the Amendment refers directly to a judicial role in resolving such elections. Still, the political question doctrine, considered as a doctrine, requires not atmospherics but an analysis of constitutional text.

Atmospherics may influence the way one looks at constitutional text, however. In Walter Nixon, the Supreme Court framed its discussion of the meaning of the word try by first discussing the meaning and role of the word sole in the phrase, "sole Power to try all Impeachments."111 Formally speaking, that analysis was not responsive to Judge Nixon's claim, but the atmospherics of the impeachment clause seem to have induced the Court to find that there were no judicially manageable standards for determining the meaning of try.

The precise question to ask is: Is there a demonstrable textual commitment of the Article II question to Congress? Here it is important to describe the Article II question carefully. The Article II question is not a general or abstract one, such as: Does the Constitution give the courts a role in resolving disputed presidential elections? Rather, it is this: Did the Florida Supreme Court exceed the discretion granted it by the Florida legislature in interpreting Florida election law as applied in a presidential election? The political question issue, then, is whether there is a textually demonstrable commitment to the political branches of the power to

109. See Steven Calabresi, A Political Question, in BUSH V. GORE: THE QUESTION OF LEGITIMACY (2002); $c f$. Chemerinsky, supra note 106, at 1105-09 (arguing that the equal protection claim also presented a political question).

110. In addition to Calabresi, supra note 109 , see also Rachel E. Barkow, More Supreme Than Court?: The Fall of the Political Question Doctrine and the Rise of Judicial Supremacy, 102 COLUM. L. REV. 237 (2002); JESSE H. CHOPER, WHY THE SUPREME COURT SHOULD NOT HAVE DECIDED THE PRESIDENTIAL ELECTION OF 2000 (Univ. of Calif.-Berkeley Public Law and Legal Theory Working Paper Series, Working Paper No. 65,2001 ) (on file with North Carolina Law Review).

111. 506 U.S. 224, 229 (1993) (quoting U.S. CONST. art. I, § 2, cl. 5). 
answer that question. The answer might be influenced by the atmospherics of the Twelfth Amendment, but it cannot be determined by language in that Amendment dealing with problems other than the one presented in Bush v. Gore.

The political question argument gets its force from the provision on counting the ballots cast by the electors: "[T]he President of the Senate shall, in the presence of the Senate and House of Representatives, open all the certificates and the votes shall then be counted." 112 The Constitution says that the Senate and the House shall be present, and says nothing about judges having any role. Further, if no candidate has a majority of the electoral votes cast and counted (by whatever means), the choice of who is to become President devolves upon the House of Representatives. ${ }^{113}$ So far, then, the Twelfth Amendment does not seem to contemplate a role for the courts.

There is more to say, however. Start with the passive voice: "shall then be counted." Does the constitutional text commit to anyone in particular resolution of disputes over which votes should be counted? Here the problem is analogous to that in Goldwater $v$. Carter: ${ }^{14}$ There the Constitution said something about entering treaties but nothing about getting out of them; here the Constitution says something about counting electoral votes but nothing about what to do when someone says, "This isn't a valid vote." In Goldwater, then-Justice Rehnquist treated constitutional silence as supporting the conclusion that the political question doctrine made nonjusticiable the claim that the Senate had to participate in treaty abrogation. ${ }^{15}$ Perhaps, however, the foreign affairs context made Goldwater special for Justice Rehnquist. ${ }^{116}$ The domestic context of Bush v. Gore may have allowed him and Justices Scalia and Thomas to treat the constitutional silence over resolving disputes over electoral votes as permitting courts to exercise their traditional role of interpreting the Constitution, as Justice Powell said in Goldwater. ${ }^{117}$

With this view of the Twelfth Amendment in hand, we can examine a simpler defense of the proposition that the Constitution did not commit the Article II claim to Congress. The Twelfth Amendment begins with the words, "The Electors shall meet in their

112. U.S. CONST. amend. XII.

113. Id.

114. 444 U.S. 996 (1979).

115. Id. at 1003 (Rehnquist, J., concurring).

116. Id. (noting that the case "involves foreign relations").

117. Id. at 997 (Powell, J., concurring). 
respective states." 118 The dispute in Bush v. Gore involved identifying exactly who the electors were, and nothing in the Twelfth Amendment suggests that resolving disputes over identity is committed to Congress. ${ }^{119}$ The electors referred to in the Twelfth Amendment are the Bush electors, if that Amendment restricts a state legislature's ability to delegate interpretive authority to state courts, or if the Florida Supreme Court exceeded the bounds of what the legislature had delegated to it. The questions of whether the Amendment does restrict state legislatures and whether the Florida Supreme Court acted impermissibly are classically legal questions ordinarily committed to the courts for resolution.

It is at the least not obvious that the Constitution contains a demonstrable textual commitment of the Article II question to Congress. The availability of judicial standards to determine whether the Florida Supreme Court so deviated from ordinary statutory interpretation as to displace the legislature as the body defining the manner of selecting electors is clear, no matter how controversial the application of those standards might be. This question involves no "initial policy determination," and of course there was no "political decision already made" that counseled in favor of "unquestioning adherence." 120

The only component of the Baker v. Carr standards that might support the conclusion that the Article II claim presented a political question, other than the "textual commitment" standard, is that "undertaking independent resolution" might "express[] lack of the respect due coordinate branches of government."121 After all, nothing in the Constitution says that Congress cannot resolve disputes over who the electors are or over which votes should be counted..$^{122}$ Further, the most cogent retrospective defenses of Bush v. Gore are

118. U.S. CONST. amend. XII.

119. Perhaps one can read the Twelfth Amendment to remit to Congress the choice of which electors to count in the event that it receives two slates from a single state. A federal statute establishes an elaborate procedure for Congress to use in making that choice, which commentators have taken as indicating Congress's belief that it had at least the first word in determining which votes to count. But, of course, that is true of all constitutional questions. It is not clear to me that the enactment of a statute governing how to count disputed electoral slates demonstrates that the Constitution gives Congress both the first and last words on which slate should be counted.

120. See Baker v. Carr, 369 U.S. 186, 217 (1962).

121. Id.

122. And, of course, in the nation's only prior experience with a similar election problem, the 1876 election, Congress did resolve these questions by appointing a commission whose report it adopted. See CHARLES FARMAN, FIVE JUSTICES AND THE ELECTORAL COMMISSION OF 1877 (1988). 
that the Court acted properly to avert a constitutional crisis. ${ }^{123}$ Yet, that crisis would have consisted of actions by one of the political branches, and perhaps both. ${ }^{124}$ Suggesting that the courts must act because the political branches would, if left alone, provoke a constitutional crisis seems rather close to expressing a lack of the respect due those branches.

What is most notable about Bush v. Gore in the present context is that no one said anything at all about justiciability questions. I do not claim that the case should actually have been dismissed for lack of standing or because it raised a political question. I do claim that the justiciability questions are obvious to someone schooled in the Bickel tradition, and that to such a person, the silence in Bush v. Gore about justiciability is quite remarkable. But, of course, a person attuned to the justiciability questions is a person whose legal consciousness was shaped in a period that has now passed.

\section{BICKEL'S WORLD, AND OURS ${ }^{125}$}

Bickel gave a catalogue of "the foundation[s]" of the political question doctrine that sounds quite different from the doctrinalized criteria in Baker v. Carr:

(a) the strangeness of the issue and its intractability to principled resolution; (b) the sheer momentousness of it, which tends to unbalance judicial judgment; (c) the anxiety, not so much that the judicial judgment will be ignored, as that perhaps it should but will not be; (d) finally ("in a mature democracy"), the inner vulnerability, the self-doubt of an institution which is electorally irresponsible and has no earth to draw strength from. ${ }^{26}$

Bickel's catalogue not only sounds quite different from Baker $v$. Carr's, it invokes prudential concerns quite remote from the legal

123. See, e.g., RICHARD POSNER, BREAKING THE DEADIOCK: THE 2000 ELECTION, THE CONSTITUTION, AND THE COURTS (2001) (discussing the presidential election of 2000 and legal aftermath, as well as defending the Court's intervention because of the political and constitutional crisis).

124. The characterization of action by the political branches as a crisis depends in addition on the delay occasioned by the necessity for the political branches to act. The idea appears to be that there was a crisis because the nation might not know who its next president would be until January. There are, however, many things a nation's people would benefit from knowing earlier rather than later, such as next year's inflation rate, and in the circumstances of late 2000 , uncertainty about who the President would be does not seem much different from many of those other things.

125. The title intentionally echoes Robert A. Burt, Alex Bickel's Law School and Ours, 104 YALE L.J. 1853, 1853 (1995), and the argument is at least kin to Burt's.

126. BICKEL, supra note 1 , at 184. 
ones Justice Brennan articulated. Bush v. Gore shows how foreign Bickel's intellectual universe is from ours. In particular, Bickel's catalogue includes items arguably not present in Bush v. Gore: anxiety and self-doubt.

The equal protection question was strange, as the Court's reluctance to develop any doctrine indicates, but as the aftermath of Baker v. Carr showed, initial strangeness does not foreclose the possibility of developing principles (in the Wechslerian sense) to resolve it and its cousins. The issue in Bush v. Gore was unquestionably momentous, and virtually everyone thinks that someone's judgment was distorted: Bush's supporters think that the justices of the Florida Supreme Court were out of control, ${ }^{127}$ and Vice President Gore's supporters think that the U.S. Supreme Court's majority acted in an entirely partisan manner. ${ }^{128}$

More interesting, I think, is that Bickel's remaining items make no appearance in Bush v. Gore. Anxiety never attended the Supreme Court majority's decision, and particularly not anxiety over the possibility that the nation would comply with a mistaken decision. A certain kind of positivism seems to have settled in along with the nation's acceptance of a theory of strong judicial supremacy. ${ }^{129}$ That is, our only worry is that the nation will not comply with the Court's decisions. Compliance is unproblematic because we no longer have available to us the sense that a Court decision might be mistaken. Nor, finally, did anyone on the Court demonstrate self-doubt or a sense of inner vulnerability.

The proximate reason for the foreignness of Bickel's formulation to today's constitutional sensibility, I think, is the acceptance in our political and legal culture of a strong form of judicial supremacy that was only uncertainly accepted when Baker $v$. Carr was decided. The ultimate reason, though, lies in the political setting in which today's

127. See, e.g., Richard A. Epstein, In Such Manner as the Legislature Thereof May Direct: The Outcome in Bush v. Gore Defended, in THE VOTE: BUSH, GORE, \& THE SUPREME COURT, supra note 97, at 11 (criticizing the Florida Supreme Court as turning the "original electoral system, as directed by the legislature, on its head"). Criticism of the Court's dissenters on this ground is less common, but $I$ have run across it, mostly in the form of the observation that only someone whose judgment was distorted could fail to recognize how out of control the Florida Supreme Court was.

128. See, e.g., ALAN M. DERSHOWITZ, SUPREME INJUSTICE: How THE HIGH COURT HIJACKED ELECTION 2000, at 3 (2001) (criticizing the Supreme Court for substituting its own political judgment for the will of the voting public and arguing that, as a consequence, the majority undermined the moral authority of the Court); Bruce Ackerman, The Court Packs Itself, AM. PROSPECT, Feb. 12, 2001, at 48, 48.

129. See sources cited in note 127 supra for indications of a commitment among legal scholars to a theory of strong judicial supremacy. 
Court operates. ${ }^{130}$ I have already emphasized the effect doctrinalization has on prudential analysis. The second element we must examine is the historical setting in which the Court Bickel and Scharpf analyzed operated, and the setting of today's Court.

Bickel and Scharpf were right to see that the task of combining prudence and law was particularly important for the time at which they wrote. They were dealing with a Supreme Court that had only recently emerged from the crisis precipitated by the Court's obstruction of the New Deal and that was simultaneously attempting to redefine the scope of government power by developing civil rights and civil liberties restrictions on government power. ${ }^{131}$ Bickel's mentor Felix Frankfurter was centrally concerned with the legacy of the pre-New Deal Court, but clearly believed that judicial power should be used to achieve racial justice. ${ }^{132}$ For Frankfurter and Bickel, success required that the Court carefully calculate when it could succeed in disciplining local and national majorities that acted against the vision of civil rights and civil liberties to which Frankfurter and Bickel were committed.

Sympathetic with the main thrust of the Warren Court's decisions through the early 1960s, Bickel was concerned that the Court would not be able to sustain its initiatives unless the Court acted with prudence. The setting in which he wrote provides the key to his interest in justiciability doctrines and to their disappearance. Southern members of Congress had attacked the Court in 1956 over Brown v. Board of Education. ${ }^{133}$ In 1959 the Conference of State Chief Justices challenged the Court over some of the Court's preemption and criminal procedure decisions. ${ }^{134}$ The Court had weathered a substantial effort to restrict its jurisdiction in 1958-59, which Chief Justice Warren later said "came dangerously close to passing."135 Baker v. Carr came in 1962, only four years after the Court had articulated the strongest theory of judicial supremacy it could, in response to defiance of its desegregation decisions by the

130. See infra notes $142-50$ and accompanying text.

131. For essays on the New Deal crisis and the Court's response, see WILliam E. LEUCHTENBERG, THE SUPREME COURT REBORN: THE CONSTITUTIONAL REVOLUTION IN THE AGE OF ROOSEVELT (1995).

132. For a discussion of Frankfurter's complex position in the school desegregation cases of 1954-1955, see MARK V. TUSHNET, MAKING CIVIL RIGHTS LAW: THURGOOD MARSHALl AND THE SUPREME COURT, 1936-1961, at 192-93, 203-04 (1994).

133. See BICKEL, supra note 1, at 256-58 (quoting the Southern Manifesto).

134. See lucas S. Powe, The WARREN COURT AND AMERICAN Politics 203-04 (2000) (describing the reaction to the Court's decisions).

135. Id. at 133 (quoting Chief Justice Warren). 
governor of Arkansas. ${ }^{136}$ The Court's reapportionment and school prayer decisions provoked a substantial adverse reaction in Congress. ${ }^{137}$

These developments led Bickel to conclude that success in the Court's reformist enterprise, with which he generally agreed when he wrote The Least Dangerous Branch, required that the Court act with prudence. Bickel sometimes saw prudence embodied in the Court's actions, as in its adoption of the "all deliberate speed" formula for desegregation. ${ }^{138}$ But, prudence also sometimes meant that the Court should not act. Judicial action had to be principled, and sometimes principle-faithfully adhering to legal principle-would actually lead the nation astray. Justiciability doctrines would give the Court additional tools to avoid harm to itself or to the nation.

As it happened, the Court had a different view of what prudence required than Bickel. He thought that prudence required caution; the Warren Court thought, probably correctly, that boldness was at least as prudent a course. Even so, the Warren Court, composed mainly of seasoned politicians, ${ }^{139}$ agreed with Bickel that the Court was a political institution.

The Court weathered the assaults on it during the early 1960s. Since then political liberals, recalling the triumphs of the Warren Court, and political conservatives, savoring the prospect of getting the Supreme Court on their side, have gone along with judicial supremacy. ${ }^{140}$ Of course, the Court itself has been quite comfortable in asserting its own supremacy. ${ }^{141}$ Nor do any current Justices appear to believe that law, faithfully invoked, might sometimes be bad for the country.

136. Cooper v. Aaron, 358 U.S. 1, 18 (1958).

137. See PowE, supra note 134 , at 139 (discussing the Conference criticism).

138. BICKEL, supra note 1 , at 247-54.

139. See Mark Tushnet, Constitutional Interpretation, Character, and Experience, 72 B.U. L. REV. 747, 757 (1992).

140. The examples I use, somewhat self-defensively, are the reviews of my book, TAKING THE CONSTITUTION AWAY FROM THE COURTS (1999), which challenged judicial supremacy. For liberal reactions defending judicial supremacy, see Erwin Chemerinsky, Losing Faith: America Without Judicial Review, 98 MICH. L. REv. 1416 passim (2000) (book review); and James E. Fleming, The Constitution Outside the Courts, 86 CoRnell L. REV. 215 passim (2000) (book review); for conservative reactions doing so, see Joan Larsen, Constitutionalism Without Courts?, 94 Nw. U. L. REv. 983 passim (2000) (book review); Saikrishna Prakash, America's Aristocracy, 109 YALE L.J. 541 passim (1999) (book review).

141. The best example, because the assertion of judicial supremacy elicited no disagreement from within the Court, is City of Boerne v. Flores, 521 U.S. 507 (1997). 
Today's version of judicial supremacy, however, has a different foundation from the one on which the Warren Court rested. As I have suggested, the Warren Court asserted judicial supremacy because it believed that judicial supremacy was a politically astute method of achieving its political goals. In contrast, today's Justices see the Court as an institution devoted to law alone. The doctrinalization of justiciability law is untroubling to today's Court, because it sees no need for approaches-they cannot be called doctrines-that would allow them to temper law with prudence.

Professor Cass Sunstein, Bickel's jurisprudential heir, has argued that the Court should incorporate prudence into its decisionmaking. ${ }^{142}$ In contrast to Bickel's views, prudence to Sunstein operates as a component of judgments on the merits. Sometimes, according to Sunstein, the Court should act boldly-rendering what Sunstein calls maximalist decisions. However, on certain occasions, such as when there is a novel but pressing issue that should be decided on its constitutional merits, the Court should be more cautious and act in a "minimalist way."143 The reasons that make minimalism sometimes appropriate, in Sunstein's view, are not identical to the ones that, for Bickel, should lead to a prudential abstention from decision on the merits, but they are at least cousins of Bickel's reasons.

A parallel development has occurred on the Court as well. Frankfurter's heirs on the Court are today's balancers, who articulate doctrines that allow them to decide cases on the merits while preserving the possibility of a different decision should circumstances change. ${ }^{144}$ For the balancers, that is, prudence is a component of judgment but not an element of legal doctrine.

In the 1950s and 1960s, balancing decisions were thought to be conservative relative to the positions taken by the Warren Court majority and, more important for present purposes, they were thought to be inconsistent with the demands imposed on judicial decision-making by the rule of law. ${ }^{145}$ The political valence of

142. Cass R. Sunstein, One Case at a Time: Judicial Minimalism on the SUPREME COURT 5, 9-14 (1999).

143. Id.

144. Among the Court's recent cases, Eastern Enterprises v. Apfel best illustrates the balancing phenomenon. 524 U.S. 498, 522-38 (1998) (conducting a balancing of factors to determine whether a regulatory taking in violation of the Fifth Amendment had occurred).

145. See, e.g., Laurent B. Frantz, Is the First Amendment Law?-A Reply to Professor Mendelson, 51 CAL. L. REV. 729, 729-32 (1963) (framing "balancing" as a "technique" for making a purely prudential choice between alternatives that are "equally permissible"). 
balancing has changed: Relative to the most prominent advocates of the rule of law as a law of rules, ${ }^{146}$ balancing is a liberal technique. ${ }^{147}$ It is now reasonably common to describe today's Court as a conservative version of the Warren Court. ${ }^{148}$ It is that, but only in a sense. Like the Warren Court, today's Court has no general constitutional theory that cautions against invalidating statutes. But the Warren Court, believing that constitutional law was an exercise in political decision-making, acted boldly when and because it thought it could accomplish its political goals by doing so. Today's Court acts boldly because it believes the law requires it to do so.

Why is today's Court in a position to act in that way? Precisely because it is not under imminent threat of retaliation. For the Warren Court, it was a close question whether legislative majorities could be assembled to challenge the Court's decisions. Today we have a divided government, which means that court decisions can be overturned or successfully challenged only if a substantial majority of the people disagrees with the Court. ${ }^{149}$ But, on that question, the facts surrounding Bush v. Gore can be taken as emblematic. The members of today's Court know that whatever they do, close to half of the nation's people will think they did the right thing. After Bush v. Gore, neither the Court nor its defenders thought it disrespectful to assume that leaving resolution of the election dispute to Congress would either provoke or itself be a constitutional crisis. In contemporary circumstances, a constitutional jurisprudence of boldness predicated on refusing to temper legal with political judgment is a politically sound jurisprudence. ${ }^{150}$

146. The reference here is obviously Antonin Scalia, The Rule of Law as a Law of Rules, 56 U. CHI. L. REV. 1175 passim (1989).

147. Again, Gerald Gunther saw this connection first. Gerald Gunther, In Search of Judicial Quality on a Changing Court: The Case of Justice Powell, 24 STAN. L. REv. 1001, 1005-06 (1972) (discussing how Justice Harlan employed "balancing" to broaden First Amendment rights, a tactic emulated by Justice Powell later to strengthen First Amendment rights and other civil liberties). I suspect that Gunther would have a different account of the origins of his perception.

148. See, e.g., John C. Jeffries, Jr. \& Daryl Levinson, The Non-Retrogression Principle in Constitutional Law, 86 CALIF. L. REv. 1211, 1212 (1998); Donald H. Zeigler, The New Activist Court, 45 AM. U. L. REV. 1367 passim (1996).

149. For an introduction to the argument, see Mark Tushnet, Foreword: The New Constitutional Order and the Chastening of Constitutional Ambition, 113 HARV. L. REV. 29,63-107 (1999) (demonstrating that change in the Court's political role by contrasting it with the Warren Court and the New Deal/Great Society regime).

150. Why today's Justices believe-if they do-that faithful adherence to law can never damage the nation is another question, and one to which $I$ have no answer. 


\section{CONCLUSION}

The story of Baker v. Carr combines two elements. First, doctrinalization substantially reduced the possibility of the Court's deploying the political question and standing doctrines in the service of prudential judgments about what would be the best structures of governance in a democratic society. Second, the Warren Court's legacy was a theory of judicial supremacy accepted along every point of the political spectrum. No one likes every Supreme Court decision, but everyone hopes-in my view, against hope-that the Court will eventually decide every case in accordance with her own views. No one, therefore, is willing to say that judicial supremacy is in principle a bad thing. When Bickel wrote a generation or two ago, that possibility was available in the legal and political culture. I think we should retrieve it, but I do not think we will. 
